\title{
Ó, borg mín, borg
}

\section{Um Vilhjálm frá Skáholti}

Sem nýjung í pessu pemahefti um borgina birtist hér fjölmála safn pýðinga á fyrsta versi kvæðisins „Ó, borg mín, borg“ eftir Vilhjálm (Björgvin Guðmundsson) frá Skáholti (1907-1963). Kvæðið birtist fyrst á íslensku og pví næst pýðingar pess á átta tungumálum - par með talið íslenska táknmálinu. Pýðingarnar eru settar fram í stafrófsröð eftir tungumálum (rituðum) og birtast á dönsku, ensku, frönsku, ítölsku, rússnesku, spænsku, býsku og að lokum er býðing á íslenska táknmálinu á myndbandi. Kveikja pessa frumkvæðis á ekki hvað síst rætur að rekja til pess að allt frá pví Haukur Morthens, vinur Vilhjálms, gerði lag við kvæðið öðlaðist pað sérstakan sess sem lofsöngur um höfuðborg Íslands, Reykjavík. ${ }^{1}$

Vilhjálmur var fæddur í Skáholti við Drafnarstíg í Reykjavík og kenndi sig við fæðingarstað sinn. Hann bjó alla tíð í Reykjavík - utan einn vetur að hann dvaldi í Askov, á Suður-Jótlandi. Ýmis störf stundaði hann samhliða skáldskapariðkun, en pekktastur var hann án efa fyrir eins konar skransölu og blómabúð sem hann rak í miðborginni.

Um Vilhjálm og skáldferil hans segir í samantektinni „Merkir Íslendingar":

Hann var Reykjavíkurskáld í húð og hár, tilfinningaríkt og eirðarlaust náttúrubarn og drykkfellt alpýðuskáld sem lá ekki lengi yfir ljóðum sínum né skeytti um brothætt mannorðið. [...] Vilhjálmur er oft sjálfmiðaður, sjálfsgagnrýninn og angurvær pó að hann verji breyskan bróður og beri höfuð hátt í allri sinni ógæfu. ${ }^{2}$

1 Annað kvæði Vilhjálms, við lag Sigfúsar Halldórssonar, „Litla fagra, ljúfa vina“ hefur einnig verið á allra vörum um árabil.

2 Til frekari upplýsinga sjá Morgunblaðið, 29. desember, 2014, bls. 27. 
Vilhjálmur sendi frá sér ljóðabækurnar Neturljóð (1931), Vort daglegt brauð $(1935)^{3}$, Sól og menn (1948) og Blóð og vín (1957). Sýnisbók kvæða hans Jarðnesk ljóð kom út 1959 og árið 1992 var heildarsafn verka hans Rósir í mjöll, sem Helgi Sæmundsson bjó til prentunar, gefið út, enda bækurnar löngu uppseldar og ófáanlegar. Vilhjálmur var málsvari lítilmagnans. Í umfjölluninni um merka Íslendinga, sem vitnað er til hér að framan, segir um Vilhjálm frá Skáholti: „Hann skipar sér á bekk með róttækustu málsvörum verkalýðsbaráttu og heimsbyltingar og ræðst auk pess á hræsni og skinhelgi góðborgaranna með hispurslausum hugleiðingum um sjálfan sig og frelsarann". 4

Í kvæðinu „Ó, borg mín, borg“ ber pó mest á angurværðinni. Ljóðmælandinn mærir borgina og gerir fegurð hennar að umtalsefni. Uppvaxtarár „barnsins unga“ mótast af strætum og lágreistum byggingum miðborgarinnar og í huga „lítils barns“ skorðast ljúf minning sem hann yljar sér við síðar á ævinni. Í síðustu versum kvæðisins verður tjörnin að eins konar leiðarstefi og táknmynd pess sem aðgengilegt er og óaðgengilegt í senn. Hólminn, álftir og kríur verða til pess að hann andvarpar og segir: „Ó ljúfa borg, ég lofa allt pitt glingur,/ sem liggur fágað kringum Arnarhól.“

Sjá glingur pitt er gjöf úr helgum sjóði, sumt glitrar eins og helgilín í kór.

Раð minnir mig í litum og í ljóði

á lítinn dreng, sem práði að verða stór.

Hólmfrìur Garðarsdóttir tók saman.

\section{HólmfríĐur GarĐarsdótTir}

Prófessor í spænsku

Mála- og menningardeild

Hugvísindasviði Háskóla Íslands

Brynjólfsgötu 1

IS-101 Reykjavík, Ísland

holmfr@hi.is

3 Bókin var endurútgefin árið 1950.

4 Morgunblaðið, 29. desember, 2014, bls. 27. 


\section{Ó, borg mín, borg*}

Ó, borg mín, borg, ég lofa ljóst pín stræti, pín lágu hús og allt, sem fyrir ber. Og pótt svo tárið oft minn vanga væti, er von mín einatt, einatt bundin pér. Og hversu sem að aðrir í pig narta, pig eðla borg, sem forðum prýddir mig, svo blítt, svo blítt sem barnsins unga hjarta er brjóst mitt fullt af minningum um pig. [...]

Um síð, um síð ég kem og krýp pér aumur og kyssi jafnvel hörðu strætin pín, pví af pér fæddist lífs míns ljósi draumur, eitt lítið barn, og par var ástin mín.

Vilhjálmur frá Skábolti

* Kvæði Vilhjálms „Reykjavík“, betur bekkt sem sönglagið „Ó borg, mín borg“, í flutningi Hauks Morthens (sjá: https://www.youtube.com/watch?v=5TTmmHIDzjE), birtist fyrst í Vort daglega brauð (1935). Hér er stuðst við framsetningu pess í Rósir í mjöll: Ljóðasafn, sem Helgi Sæmundsson bjó til prentunar, Reykjavík: Hörpuútgáfan, 1992, bls. 98-101. Um fyrsta erindi kvæðisins er að ræða ásamt broti úr pví næstsíðasta. 


\section{DANSKA}

\section{O by, min by}

O by, min by,

min pris nu dine gader finder,

de lave huset, alt, som øjet møder.

Og selvom tårer ofte væded' mine kinder:

du ser vel: håbet altid for dig gløder.

Om dig lad andre tale ilde, min ædle by, som fordum var min pryd, så blidt som barnets unge kilde er mine minder om dig blot en fryd.

Til sidst, til sidst jeg ydmygt kryber ned og kysser dine hårde gader med begærlighed for livets drøm blev født på dette sted, et lille barn, det var min kærlighed.

Pýð̋ing: Gísli Magnússon

Gísli Magnússon

Dósent í dönsku

Mála- og menningardeild

Hugvísindasviði Háskóla Íslands

Brynjólfsgötu 1

IS-101 Reykjavík, Ísland

gislim@hi.is 


\section{ENSKA}

\section{My Town}

Oh, my town, my town

I praise your ways and streets so dear,

Your little houses and all that I see.

For though oft down my cheek will run a tear, My hopes are constantly tied to thee.

No matter others do not take your part, My beloved town which nurtured me So tender, tender, as a baby's heart, My breast is full of memories of thee

At last to you I sadly bend my knee Even kiss the hard stony streets I knew Because they gave birth, gave my dream to me, The child who was to be my love so true.

Pýðing: Júlían M. D’Arcy

JúLÍAN M. D'Arcy

Prófessor í ensku

Mála- og menningardeild

Hugvísindasviði Háskóla Íslands

Brynjólfsgötu 1

IS-101 Reykjavík, Ísland

jaydarcy@hi.is 


\section{FRANSKA}

\section{O ville ma ville}

O ville ma ville

Je chérie tant tes avenues

Tes maisons basses et ton joli décor.

Même si souvent une larme coule sur ma joue

Mon espoir est toujours toujours toi.

Même si d'autres te maudissent

Toi, noble ville qui autre fois me parait.

Doux si doux comme celui d'un enfant

Mon coeur bat de souvenirs de toi.

Plus tard je viendrai humble devant toi

J'embrasserai même ton dur pavé

Puisque de toi est né le rêve clair

Un bel enfant qui devint mon amour.

Pýðing: Ásta Ingibjartsdóttir

og Francois Frans Heenen

\begin{tabular}{|c|c|}
\hline Ásta INGIBJARTSDÓTTIR & Francois Frans Heenen \\
\hline Aðjunkt í frönsku & Aðjunkt í frönsku \\
\hline Mála- og menningardeild & Mála- og menningardeild \\
\hline Hugvísindasviði Háskóla Íslands & Hugvísindasviði Háskóla Íslands \\
\hline Brynjólfsgötu 1 & Brynjólfsgötu 1 \\
\hline $\begin{array}{l}\text { IS-101 Reykjavík, Ísland } \\
\text { astaingi@hi.is }\end{array}$ & $\begin{array}{l}\text { IS-101 Reykjavík, Ísland } \\
\text { ffh@hi.is }\end{array}$ \\
\hline
\end{tabular}




\section{ÍTALSKA}

\section{$\mathrm{O}$ città, mia città}

$\mathrm{O}$ città, mia città, io canto le tue strade luminose, le basse case e tutto quel che appare. Spesso una lacrima il viso mi riga ma la speranza sempre, sempre a te mi lega.

Lascia che gli altri ti rodano pure, città sublime, che un tempo mi ornavi. Lieve, lieve come del bimbo il cuore è il petto mio ricolmo di ogni tuo ricordo.

Mi arrendo infine, infine vengo a te, mi prostro e bacio le tue strade dure. Perché da te radioso è nato il sogno di questa vita: un piccolino, tutto il mio amore.

Pýðing: Stefano Rosatti

Stefano Rosatti

Aðjunkt í ítölsku

Mála- og menningardeild

Hugvísindasviði Háskóla Íslands

Brynjólfsgötu 1

IS-101 Reykjavík, Ísland rosatti@hi.is 


\section{RÚSSNESKA}

\section{Мой городок}

Мой городок, к домишкам невысоким

И светлым улочкам со всех сторон Пусть слёзы часто орошают щёки Надеждой неизменно устремлён.

И заново при каждом приближеньи Ты, благородный, осветишь мой путь. Как нежное дитя, приду в смущенье. Воспоминанья переполнят грудь.

Паду я благодарно на колени, Страданием души изнемождён: Ибо из самых светлых побуждений Аюбовь моя и сам я здесь рождён.

Pýðing: Svetlana Súvorova

Svetlana Súvorova

Framkvæmdastjóri og býðandi

Býr í Moskvu, Rússlandi nyckiss@list.ru 


\section{SPAENSKA}

\section{Oh mi ciudad}

Oh mi ciudad, yo canto a tus calles, tus casas bajas y tu humildad. Y aunque el llorar mi cara triste apague, mis esperanzas contigo estarán.

Si bien la gente tanto te censura, noble ciudad, tú honraste mi niñez. Tu alma joven Ilena de ternura mi corazón recordando el ayer.

Hoy a tus pies me postro cuando vuelvo, tus duras calles beso con dolor. Porque de ti nació una vida, un sueño, un pequeñín que fue mi gran amor.

Oh mi ciudad.

Pýðing: Steinunn Björk Ragnarsdóttir og Elías Portela

SteinunN BJörk RAgNaRSDótTIR Stundakennari í spænsku Mála- og menningardeild Hugvísindasviði Háskóla Íslands Brynjólfsgötu 1 IS-101 Reykjavík, Ísland sr@hi.is
Elías Portela Pýðandi og ljóðskáld Býr í Reykjavík epf@hi.is 
PÝSKA

\section{Meine Stadt}

Meine Stadt. Oh, meine Stadt.

Ich preise deine Gassen, deine Häuschen, soweit mein Auge reicht.

Wenn auch Tränen meine Wangen nässen, nimmst du mir die Hoffnung doch nie.

Mögen andere dich schelten, meine geliebte Stadt, wo meine Wiege stand, so zart wie eines Kindes Herz wohnt die Erinnerung an dich in meiner Brust.

Zu guter Letzt mein Knie zu Boden sinkt, mein Kuss deine steinigen Straßen berührt dort, wo es das Licht der Welt erblickte, das Kind, das meine Liebe ward.

Pýðing: Sabine Leskopf

SABine Leskopf

Pýðandi, túlkur og borgarfulltrúi

Langholtsvegi 87

IS-104 Reykjavík, Ísland

sabine@hi.is 


\section{ÍSLENSKT TÁKNMÁL}

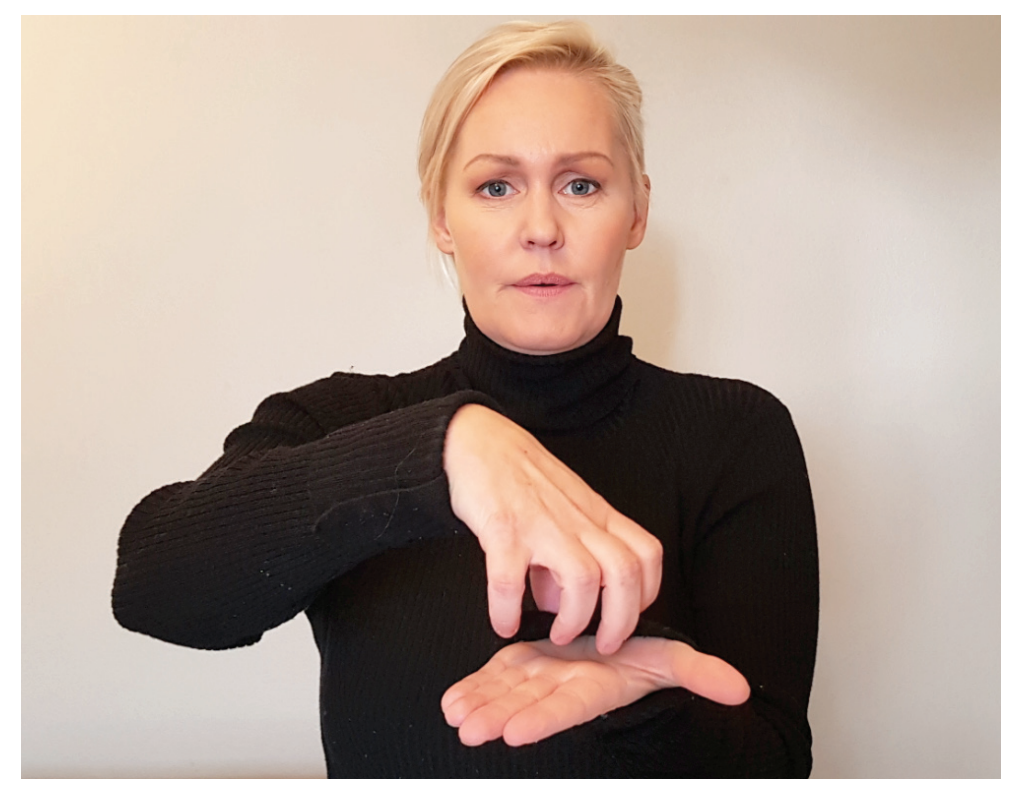

Pýðing: Elsa G. Björnsdóttir

\section{ElsA G. BJöRnSDÓtTIR}

Pýðandi og táknmálstúlkur

Samskiptamiðstöð heyrnarlausra og heyrnarskertra

Grensásvegi 9

IS-108 Reykjavík, Ísland

elsa@shh.is 